\title{
ADAPTIVE MODEL OF CRIMINAL ACTIVITY IDENTIFICATION ON THE CASE OF THE STATE BORDER SERVICE OF UKRAINE
}

\section{Oleh Shynkaruk}

\section{INTRODUCTION}

The State Border Guard Service of Ukraine (hereinafter referred to as SBGSU) is one of the subjects of the security and defense sector, implementing the state policy in the field of state border security and protection of Ukraine's sovereign rights in its exclusive (maritime) economic zone ${ }^{1}$.

To this end, the SBGSU undertakes a series of activities, in particular: taking part in the fight against organized crime, combating illegal migration, terrorism, ending the activities of illegal militarized or armed formations (groups), organized groups and criminal organizations.

The results of the operational and service activities of the authorities and units of the SBGSU indicate that the effectiveness of the fight against crime is enhanced by timely detection of crimes, identification of their type and carrying out specific measures of prevention or counteraction according to each type of crime.

A number of information sources are used to obtain or clarify the primary data on the crime and the persons involved in it. According to the results of the analysis of the received information, its authenticity and conformity with the available crime data (models of a specific type of crime) are evaluated.

Since the time it takes to commit a crime is often less than the time for obtaining and verifying the primary information about the crime, the assessment of the level of the information sufficiency loses its relevance. Inaccurate data about the preparation or the fact of committing the crime and the persons involved in it creates unfavorable conditions for timely counteraction to it and increases the cost of resources available at the border guard agencies and units.

At the same time, each type of crime is characterized by its inherent methods (techniques) of preparation and committing. Therefore, measures to counteract a particular type of crime should be adequate to the tactics of the

\footnotetext{
${ }^{1}$ Pro nacionaljnu bezpeku Ukrajiny : Zakon Ukrajiny : vid 21.06.2018 № 2469-VIII. URL : http:// www.rada.gov.ua. (in Ukrainian)
} 
offenders. To this end, a number of hypotheses (the probable place and time of the crime, the composition of persons involved in the crime and their role, modes of action, directions and possible tricks) are put forward based on the analysis of the actions of the criminals.

Subsequently, the most plausible hypothesis is determined (a crime model is formed) and the appropriate model of crime prevention or suppression (purpose, tasks, areas of action, composition of forces and means, sequence and methods of action, expected results) is worked out. This allows to distribute forces and resources and to form accurate tasks for their use.

Thus, for the timely prevention, detection and suppression of crimes on the state border of Ukraine, it is necessary to search for such tools that would allow to identify a specific type of crime.

\section{Analysis of recent publications}

Scientific knowledge of the issues of security of the state border of Ukraine, in particular counteraction to threats, was carried out by a considerable number of scientists.

For example, in the work $^{2}$, tools were proposed to assess the state of exacerbation of the situation in the border area when assessing the dynamics of the threat to the territorial integrity of the state.

In the work ${ }^{3}$, the procedure for determining the degree of correspondence of an object of attention to the data on a potential illegal migrant at border crossing points is proposed.

In another work ${ }^{4}$, a model of detecting lawbreakers at the state border was developed using a hierarchical fuzzy logical deduction.

${ }^{2}$ Ghorodnov V.P., Binjkovsjkyj O. A., Karatajev R. Gh., Kyrylenko V. A. (2009) Metodyka vyznachennja pokaznyka stupenja zaghostrennja obstanovky v prykordonnij sferi pry ocinci dynamiky formuvannja zaghrozy terytorialjnoji cilisnosti derzhavy [The method of determining the indicator of the degree of exacerbation of the situation in the border area in assessing the dynamics of the formation of threat to the territorial integrity of the state]. Zbirnyk naukovykh pracj, no. 46. pp. 24-31. (in Ukrainian)

${ }^{3}$ Kyrylenko V. A, Gorodnov V. P, Karatayev R. G, Tsibrovskyi M. Yu. (2008) Model of determining the degree of correspondence of an object of attention to the data about a potential illegal migrant at border crossing points [Model for determining whether the object of attention is subject to data on a potential illegal migrant at border crossings]. Zbirnyk naukovykh pracj, no. 46. pp. 29-34.

4 Androshhuk O.S., Mykhajlenko O. V. (2014) Modelj vyjavlennja porushnykiv zakonodavstva na derzhavnomu kordoni iz zastosuvannjam ijerarkhichnogho nechitkogho loghichnogho vyvodu [A model for determining the degree of compliance of an object of attention with data on a potential illegal migrant at border crossings]. Modern information technologies in the field of security and defense. No.1(19). pp. 5-10. 
In the work ${ }^{5}$, a model of crime recognition was developed by the Operational Investigation Department of the State Border Guard Service of Ukraine.

In the work ${ }^{6}$, the tools for prediction unlawful activities on the state border outside the checkpoints are proposed.

The results of the analysis of these and other publications and studies indicate that the issue of the crime type identification in the area of responsibility of the bodies (units) of the SBGSU was not considered.

Therefore, the relevance of the topic of the research is stipulated by the need for an in-depth study of the problem of crime identification on the state border of Ukraine for the scientific tools formation in the operational and service activities of border protection authorities (units) for improving the effectiveness of combating crime.

The purpose of the article is to formulate an adaptive model of the criminal activity identification on the state border of Ukraine.

\section{Outline of the Main Research Material}

The State Border Guard Service of Ukraine, in accordance with Ukrainian legislation, directs its efforts of the operational service activity of the subordinate border security units to:

counteracting illegal migration, contraband and other unlawful activity at the state border controlled frontier area, at the checkpoints via the state border of Ukraine, border control enter-exit points;

participation in the activities directed to combating terrorism, to stop the activities of illegal or combatant formations (groups), organized groups and criminal organizations revealing and stopping criminal offenses, etc. .

According to the tasks assigned and specific character of the SBGSU operational-service activity, individually or in interaction with other lawenforcement agencies and services it accomplishes counteraction (prevention, disclosing, termination) against the crimes indicated in the

5 Cyghykal P. O, Farion O. B. (2017) Modelj rozpiznannja zlochyniv operatyvnorozshukovym viddilom Derzhavnoji prykordonnoji sluzhby Ukrajiny [Model of crime recognition by the Operational Investigation Division of the State Border Guard Service of Ukraine]. Zbirnyk naukovykh pracj, no. 1(71). pp. 238-255.

${ }^{6}$ Onyshhuk S. V. (2014) Proghnozuvannja protypravnoji dijaljnosti na derzhavnomu kordoni poza punktamy propusku na osnovi nechitkoji loghiky [Predicting unlawful activities at the state border beyond the border crossing points based on fuzzy logic]. Zbirnyk naukovykh pracj, no. 3(40). pp. 198-202.

${ }^{7}$ Pro zatverdzhennja Polozhennja pro orghan okhorony derzhavnogho kordonu Derzhavnoji prykordonnoji sluzhby Ukrajiny: nakaz MVS vid 30.11.2018. \# 971. Kyjiv. URL: http://search.ligazakon.ua/1_doc2.nsf/link1/RE32920.html. (in Ukrainian) 
table 1 , responsibility for the crimes commitment which is determined by the Criminal Code of Ukraine ${ }^{8}$.

It the course of the operational-service activity of the SBGSU border protection bodies information is obtained about persons, events (unlawful events) at the state border (for example, offence commitment, detention of a person at the port-of-entry).

Table 1

List of crimes (determined by the Criminal Code articles), by the forces and means of the border protection authorities within the Ukrainian legislation

\begin{tabular}{|c|c|c|}
\hline N/n & $\begin{array}{c}\text { Article } \\
\text { number }\end{array}$ & Title \\
\hline 1 & p. 110 & $\begin{array}{c}\text { Encroachment on territorial } \\
\text { integrity and inviolability of Ukraine }\end{array}$ \\
\hline 2 & p. 149 & $\begin{array}{c}\text { Human trafficking or other } \\
\text { illegal transaction concerning a person }\end{array}$ \\
\hline 3 & p. 201 & Smuggling \\
\hline 4 & p. 249 & Illegal fishing, animal or other water production industry \\
\hline 5 & p. 255 & Creation of crime organization \\
\hline 6 & p. 258 & Terroristic act \\
\hline 7 & p. $258^{1}$ & Involvement into terroristic act commitment. \\
\hline 8 & p. $258^{2}$ & Public appeal to commit a terroristic act \\
\hline 9 & p. $258^{3}$ & Creation of terroristic group or organization \\
\hline 10 & p. $258^{4}$ & Promotion of the terroristic act \\
\hline 11 & p. $258^{5}$ & Financing a terroristic act \\
\hline 12 & p. 260 & $\begin{array}{c}\text { Creation of non - statutory paramilitary } \\
\text { or armed formations }\end{array}$ \\
\hline 13 & p. 305 & $\begin{array}{c}\text { Smuggling in drugs, psychotropic substances, their } \\
\text { analogues or precursors, false medicines }\end{array}$ \\
\hline 14 & p. 332 & $\begin{array}{c}\text { Unlawful persons transition } \\
\text { over the state border of Ukraine }\end{array}$ \\
\hline 15 & p. 333 & $\begin{array}{c}\text { Irregularities in the international transportation of goods } \\
\text { which are liable to the export control }\end{array}$ \\
\hline 16 & p. $358^{4}$ & Usage of knowingly forged document \\
\hline 17 & & Other crimes \\
\hline
\end{tabular}

This information is accumulated in the relevant databases of different kinds. Thus, information about persons who are denied to enter Ukraine according to the legislation or temporarily restricted to leave Ukraine, in

${ }^{8}$ Kryminaljnyj kodeks Ukrajiny : Zakon Ukrajiny \# 2341 III vid 05.04.2001 rok URL : http://zakon3.rada.gov.ua / laws/show/2341-14/para273. (in Ukrainian) 
accordance with the assignment of the law enforcement agencies, persons, hiding from the inquest bodies, investigation and court, avoiding to serve criminal sentences, with invalid, stolen and lost documents for the right to leave the country is received by the information-telecommunication system (further - «Gart-1»). Besides, the information of different type about events at the state border is inserted into the databases of the information and telecommunication systems (further - ITS) ${ }^{9,10,11}$ (table 2).

Table 1

\section{Databases of the information and telecommunication systems}

\begin{tabular}{|c|c|}
\hline Databases & Speciality \\
\hline «Gart-2» & ITS operational duty service \\
\hline «Gart-3» & ITS border guard service \\
\hline «Gart-5» & ITS informational analyst service \\
\hline «Gart-10» & ITS operational search service \\
\hline «Gart-12» & ITS marine security \\
\hline «Gart-14» & ITS control and coverage of the situation \\
\hline «Gart-21» & ITS internal security units \\
\hline RE & registration of the events \\
\hline RPA & risk profile analysis \\
\hline OM & operational messages \\
\hline IC & interactive reference \\
\hline CDSR & central data storehouse repository \\
\hline
\end{tabular}

In order to provide the coverage of the situation telecommunication system of geoinformation support «Gart-17» has been developed and implemented in all corporate systems. This system is kept up to date.

9 Pro zatverdzhennja Polozhennja pro informacijno-telekomunikacijnu systemu prykordonnogho kontrolju "Ghart-1" Derzhavnoji prykordonnoji sluzhby Ukrajiny : nakaz DPSU vid 30.09.2008. № 810. URL : https://zakon.rada.gov.ua/ laws/show/z1086-08. (in Ukrainian)

${ }^{10}$ Streljbicjkyj M. A. (2018) Tekhnologhija zabezpechennja funkcionaljnoji bezpeky integhrovanoji informacijnoji systemy Derzhprykordonsluzhby na stadiji modernizaciji [Technology of providing functional security of the State Border Service's integrated information system at the stage of modernization], Kiev, 348 p. (in Ukrainian)

${ }^{11}$ Shynkaruk O. M., Fedorchenko A. V. (2015) Analiz dosvidu stvorennja ta vykorystannja integhrovanykh telekomunikacijnykh system «Ghart» v Derzhavnij prykordonnij sluzhbi Ukrajiny [Analysis of the experience of creation and use of integrated telecommunication systems «Hart» in the State Border Service of Ukraine]. Zbirnyk naukovykh pracj, no. 2(64), pp. 221-233. (in Ukrainian) 
To exchange the information with the individuals of the integrated border management on the issues of prevention entry-exit for persons, who are prohibited to enter or leave Ukraine according to the legislation ITC «Arcan» is used. Besides, the information about lost (invalid) documents, information about persons, who are in search, stolen vehicles etc. Based on the analysis of information of the SBGSU databases about unlawful events at the state border of Ukraine and information obtained using the possibilities of ITC «Arcan» informational signs of crimes and persons related to them have been received. These indications in total characterize typical crime models, which are presented in table 2.

Table 2

\section{Complex of information indicators of criminal activity on the state border of Ukraine by the types of crimes counteraction to which refers to the SBGSU competency}

\begin{tabular}{|l|}
\hline Name of information indicator \\
\hline Complex No 1. Information indicators of crime "Smuggling" \\
\hline $\begin{array}{l}\text { Complex No 2. Information indicators of crime "Trafficking in persons or other } \\
\text { illegal transactions in respect of a person" }\end{array}$ \\
\hline $\begin{array}{l}\text { Complex No 3. Information indicators of crime "Smuggling of drugs, psychotropic } \\
\text { substances, their analogous or precursors and counterfeit medicines" }\end{array}$ \\
\hline Complex No 4. Information indicators of crime "Terrorist act" \\
\hline Complex No 5. Information indicators of crime "Conspiring to commit the terrorist act" \\
\hline $\begin{array}{l}\text { Complex No 6. Information indicators of crime "Organization of unforeseen } \\
\text { by law paramilitary units or armed groups" }\end{array}$ \\
\hline $\begin{array}{l}\text { Complex No 7. Information indicators of crime "Illegal human trafficking across } \\
\text { the state border of Ukraine" }\end{array}$ \\
\hline
\end{tabular}

Information indicators shown in table 2 by the sources of obtaining and contents meet different criteria of credibility which are assessed by method «4×4» in SBGSU ${ }^{12}$.

The given method allows making an assessment of credibility of information source and its contents. Thus an assessment of credibility of information sources is carried out by the following criteria:

\footnotetext{
${ }^{12}$ Pro zatverdzhennja Instrukciji pro porjadok ocinky informaciji za metodom $4 \mathrm{kh} 4:$ nakaz Administraciji Derzhavnoji prykordonnoji sluzhby Ukrajiny vid 19.01.08 \# 44. Kiev : ADPSU, 2008. 28 p. (in Ukrainian)
} 
«A»-source concerning which there is no suspicion in falsifying or distortion of information (active members of law enforcement institutions, court officials, prosecutors, evidence etc.);

$\langle\mathrm{B} »-$ indicates the possibility of an error while inputting the data and give to electronic material databases (recordings in account books, law enforcement databases etc.);

$\langle\mathrm{C} »-$ indicates the necessity of additional verification of each piece of information obtained from the source of this category;

«D»- is assigned to all new sources of information credibility of which is unknown or cannot be identified at the given moment.

The assessment of credibility of the contents is carried out according to the following criteria:

«1»- for information credibility of which is beyond any doubt;

«2»- for information known personally to the source, but unknown to the staff member who receives it;

«3»- for information known personally to the source but not confirmed by the previously received information;

«4»- for information which is personally unknown to the source and it cannot be confirmed.

Overall assessment of information credibility is displayed as the code: $A 1, A 2, B 1, B 2, A 3, A 4, B 3, B 4, C 1, C 2, C 3, C 4, D 1, D 2, D 3, D 4$.

Each element of the denoted set of information credibility can be represented by a point on the axis of abscissas and has ordinate - meaning of the indicator of basic information credibility $y_{0}$ (toward a decrease of credibility) from $16 / 16$ to $1 / 16$ on axis of ordinates respectively.

Monotony of decrease of information credibility makes it possible to approximately present the initial credibility in the form of the equation of straight line specified by points $y_{\max }\left(x_{1}\right), y_{\min }\left(x_{4}\right)^{13}$ :

$$
y_{0}=y_{\max }-\operatorname{tg} a \cdot x
$$

where: $\operatorname{tg} \varphi=\frac{y_{\max }-y_{\min }}{x_{D 4}-x_{A 1}}$;

$x$ - assessment of indicator of information credibility by method « $4 \times 44 »$;

$y_{\min }-$ minimum meaning of the indicator of information credibility;

${ }^{13}$ Ghorodnov V. P. Karatajev R. Gh., Kyrylenko V. A. (2009) Modelj vyznachennja stupenja vidpovidnosti ob'jekta uvaghy danym pro potencijnogho porushnyka v punktakh propusku cherez derzhavnyj kordon [Model for determining the degree of compliance of the object of attention to the information about the potential offender at the border crossing points]. Zbirnyk naukovykh pracj, no. 46. pp. 18-23. 
$y_{\max }-$ maximum meaning of the indicator of information credibility;

$\varphi-$ angle between the straight line and axis of abscissas.

Assessment of the degree of coherence of the initial and the necessary indicators composition is fulfilled by means of components comparison of needed and provided information vectors. Obtaining the correct data may be carried out by the results of the assessment.

Indicator of the information coherence degree $(\cos \varphi)$ may be presented as cosine of angle between vectors of needed and provided information which is calculated as:

$$
\cos \varphi=\frac{1}{a b} \sum_{i=1}^{n} a_{i} b_{i}=\gamma
$$

where: $a$ and $b$ - length of the vector of needed and provided information; $\left(a_{1}, a_{2}, \ldots, a_{\mathrm{n}}\right)$ and $\left(b_{1}, b_{2}, \ldots, b_{\mathrm{n}}\right)-$ coordinates of vectors $a$ and $b$.

Within complete coherence the angle between vectors is equal to zero $(\varphi=0)$ and $\cos \varphi=1$. Criterion of adequacy for the level of information coherence is achieved on condition $\cos \varphi \geq \gamma(0<\gamma \leq 1)$.

Let us consider as an example the process of crime identification by the provided information about its indicators.

Example. The Central office of border guard service department "Reni" of Izmail border unit of the Southern regional office SBGSU got two messages.

Message No1. May, $12^{\text {th }} 2019$ at 20.30 a group of seven people tried to buy bus tickets to Romania. But they seemed confused and failed to explain the point of their destination in Romania, then they suddenly disappeared. The information was given by the administrator of the bus terminal who provided reliable information before.

Message No 2. On May 12, 2019 at 21: 20 a group of 7 people, looking like foreign citizens, was detected near the housing cooperative "Prydunaiskyi" of Reni district. They were walking along the forest belt near Reni - Giurgiulesti highway, accompanied by a member of the cooperative, heading for his house. The information was received from an employee of Reni police department, who was resting in the country house of the abovementioned cooperative.

Task. To identify the crime according to the available information on the signs of the crime by determining the degree of compliance of the information obtained with the data of typical models of crimes (Tables 1;2).

Decision. Under the conditions of the example given, the information on message No. 1 was evaluated using method 4 as meeting the reliability 
criterion A $3=x=12 / 16$. Primary assessment of the information reliability is obtained by the formula:

$$
\operatorname{tg} \varphi=\frac{y_{\text {max }}-y_{\text {min }}}{x_{A 1}-x_{D 4}}, y_{\mathrm{n}}=y_{\text {max }}-\operatorname{tg} a \cdot x,
$$

where: $n$ is the message number.

As a result of calculations we receive a value $y_{1}=0,75$.

To determine which of the typical models of crimes the information of the received message (hereinafter - the object of attention) belongs to, it is necessary to assess the belonging of the received information (with its components) to each of the sets specified in Table 2. Here, the value of the cosine of the angle between the reference vectors of each set and the vector of the available information can be an indicator of consistency.

According to this example, it was found that the object of attention presented in table 3 in the fourth column corresponds to the set of information features No. 8.

In Table 3 the following value was assumed:

$\vec{a}_{o}$ - reference vector of information signs of a typical crime model; $\vec{b}_{1}-$ vector of available information on the message No. $1 ; 《+»-$ presence of a sign; «-»- absence of a sign.

After calculations by the formula (2) we obtain $\cos \varphi_{1}=\gamma_{8}=0,577$. Belonging of the available information signs to other sets of crimes' information signs has correspondingly smaller value $\left(\gamma_{8} \gamma_{1}, \ldots, \gamma_{7}\right)$.

If all components of the vector of available information correspond to the $\vec{b}_{1}$ components of the reference vector of the necessary information $\vec{\alpha}_{1}$, the identification of the object of attention as a crime - "People smuggling across the state border of Ukraine "is" reliable". Here, the probability of compliance of the object of attention with the standard model of the crime "People smuggling across the state border of Ukraine" will be equal to one $\left(P_{\mathrm{m}}=1\right)$, where $m$ is the number of the set of information signs of the crime (Table 2). 
Summary table of components of the reference vector of separate information signs of set No. 7 «People smuggling across the state border of Ukraine» (table 2) and the vector of available information according to the example

\begin{tabular}{|c|c|c|c|c|}
\hline \multirow[t]{2}{*}{$\begin{array}{l}\text { Seq. } \\
\text { No }\end{array}$} & \multirow{2}{*}{$\begin{array}{c}\text { Separate informational signs of the crime } \\
\text { "People smuggling across the state border } \\
\text { of Ukraine" }\end{array}$} & \multirow{2}{*}{$\begin{array}{l}\text { Reference } \\
\text { vector's } \\
\text { components } \\
\vec{a}_{o}\end{array}$} & \multicolumn{2}{|c|}{$\begin{array}{l}\text { Available } \\
\text { information vector' } \\
\text { components }\end{array}$} \\
\hline & & & $\vec{b}_{1}$ & $\vec{b}_{2}$ \\
\hline 1 & $\begin{array}{l}\text { The person is hiding not far from the state } \\
\text { border with the use of the terrain }\end{array}$ & + & - & + \\
\hline 2 & $\begin{array}{l}\text { Detection of signs of groups of persons } \\
\text { staying near the border (trampled snow, } \\
\text { cigarette butts, remnants of packaging from } \\
\text { water and food, especially those that are not } \\
\text { available in the local trade network) }\end{array}$ & + & - & - \\
\hline 3 & $\begin{array}{l}\text { The person does not speak Ukrainian or any } \\
\text { other language of EU countries, speaks an } \\
\text { unknown language }\end{array}$ & + & + & - \\
\hline 4 & $\begin{array}{l}\text { Person's appearance features testifying to its } \\
\text { possible belonging to the foreign state (skin } \\
\text { color, off-season clothes or clothes not specific } \\
\text { for citizens living in the border area, etc.) }\end{array}$ & + & - & + \\
\hline 5 & $\begin{array}{l}\text { Data on possible facilitation of illegal } \\
\text { transportation of persons across the state } \\
\text { border of Ukraine }\end{array}$ & + & - & + \\
\hline 6 & $\begin{array}{l}\text { Data on the presence of people not living in } \\
\text { the controlled border area, the border zone }\end{array}$ & + & - & + \\
\hline 7 & $\begin{array}{l}\text { Presence of people who are not members of } \\
\text { enterprises and communities engaged in } \\
\text { agricultural and other economic activities in } \\
\text { the controlled border area }\end{array}$ & + & - & + \\
\hline 8 & $\begin{array}{l}\text { Presence of premises, facilities, shelters } \\
\text { adapted for temporary and hidden stay of } \\
\text { illegal migrants in the controlled border area } \\
\text { or border zone for the purpose of their } \\
\text { further transportation across the state border }\end{array}$ & + & - & - \\
\hline 9 & $\begin{array}{l}\text { The presence of human clothing, unusual for } \\
\text { residents of border areas }\end{array}$ & + & + & - \\
\hline 10 & $\begin{array}{l}\text { The person is a citizenship of the country- } \\
\text { potential sources of illegal migrants }\end{array}$ & + & - & - \\
\hline 11 & Embarrassed and confused look of a person & + & + & - \\
\hline 12 & $\begin{array}{l}\text { The person does not have information about } \\
\text { the final destination on the territory of a } \\
\text { neighboring state }\end{array}$ & + & + & - \\
\hline 13 & $\begin{array}{l}\text { Purchase of an unusually large batch of food } \\
\text { by a local resident of the border area }\end{array}$ & + & - & - \\
\hline 14 & $\begin{array}{l}\text { Purchase of an unusually large batch of } \\
\text { goods of vital necessity by a local resident of } \\
\text { the border area }\end{array}$ & + & - & - \\
\hline 15 & $\begin{array}{l}\text { Data on persons communicating in a foreign } \\
\text { language }\end{array}$ & + & + & + \\
\hline
\end{tabular}


Otherwise, when there is a complete mismatch of all components of the vector of available information to the components of the reference vector, this incident is one that cannot happen and is "impossible", that is, the probability that the object of attention corresponds to the typical model of the specified crime will be zero $\left(P_{m}=0\right)$.

The partial coincidence of the vectors of information is characterized by the degree of their consistency and determines the importance of the probability that the object of attention is a crime related to the illegal transfer of persons across the state border of Ukraine $0 \leq P_{m} \leq 1$.

The index of the degree of information vectors consistency at full coincidence of vectors is equal to one (collinear vectors), and in case of complete difference it is equal to zero (vectors are orthogonal), and in case of complete disagreement it is equal to zero (vectors are orthogonal), which corresponds to the physical meaning of estimations and the extreme values of the probability of Pm correspondence.

However, within this range, the dependence of the degree of vector consistency is nonlinear. Therefore, the indicator of the probability of compliance of the standard model of the specified crime in the event in question may be the value of the inverse function of the indicator of vector coherence of available and reference information, $\arccos \varphi, \varphi \in\left[0 ; \frac{\pi}{2}\right]$, provided that it is reduced to a dimensionless value ${ }^{14}$ :

$$
P_{m}=1-\frac{2}{\pi} \times \arccos \left(\frac{1}{a^{m} b} \sum_{i=1}^{n^{m}} a_{i}^{m} b_{i}\right) .
$$

Formula (4) takes into account the condition of intentionally nonnegative value of the component and, therefore, the positive value of the scalar product of vectors for the evaluated information data.

As a result of additional measures taken to check the probability of compliance of the object of attention with the reference image of the model to the specified crime in this case will be equal: $\mathrm{P} 1=0.392$.

Assessment of the degree of compliance of the object of attention depends on both the probability (3), conditioned by the indicator of coherence of information vectors, reflecting the information semantic correspondence of current data to the image, which is assessed as possible,

${ }^{14}$ Medvedjev M. Gh., Pashhenko I. O. (2008) Teorija jmovirnostej ta matematychna statystyka [Probability theory and mathematical statistics]. Kiyv : «Lira-K», 536 p. (in Ukrainian) 
and on the level (1) of the ability of the source of information to provide information adequately to the event.

As a result, the assessment of the degree of compliance of the identified event with the reference image of the crime model in this case can be calculated by the multiplication probability theorem:

$$
P_{m . y}=P_{m} \times y_{0}=y_{0} \cdot\left[\frac{\pi-2}{\pi} \times \arccos \left(\frac{1}{a^{m} b} \sum_{i=1}^{n^{m}} a^{m}{ }_{i} b_{i}\right)\right] .
$$

Under the terms of the example in Message 1, the probability of an expected event (the event corresponds to a typical crime model) will equal: $\mathrm{P} 1=0,294$.

Further on, we will analyze the information on the message № 2 and get the information vector, information components of which are presented in Table 3, fifth column «Components of the existing vector $\vec{b}_{2} »$.

As a result of the calculations, similar to the processing of message № 1 , there were obtained the following data:

$$
y_{2}=0,625 ; \cos \varphi_{2}=y_{2}=0,632 ; P_{2}=0,411 \text {. }
$$

Subsequently, the total probability $(\mathrm{Pn})$ of the belonging of the information signs obtained in messages No. 1 and No. 2 of the typical crime model is determined by the following formula:

$$
P_{m}=P_{8.1}+P_{8.2}-P_{8.1} \times P_{8.2},
$$

After calculations we get $\mathrm{P} 8=0,554$. This probability of occurrence is greater than the lower limit value, which, as an example, is taken as 0.238 , and it is sufficient to take measures to prevent and combat crime.

Having time $t_{\mathrm{H}}$ there is an opportunity to make a selection of missing information signs.

The algorithm of identification of crimes based on available information about their characteristics is presented in fig. 1 . 


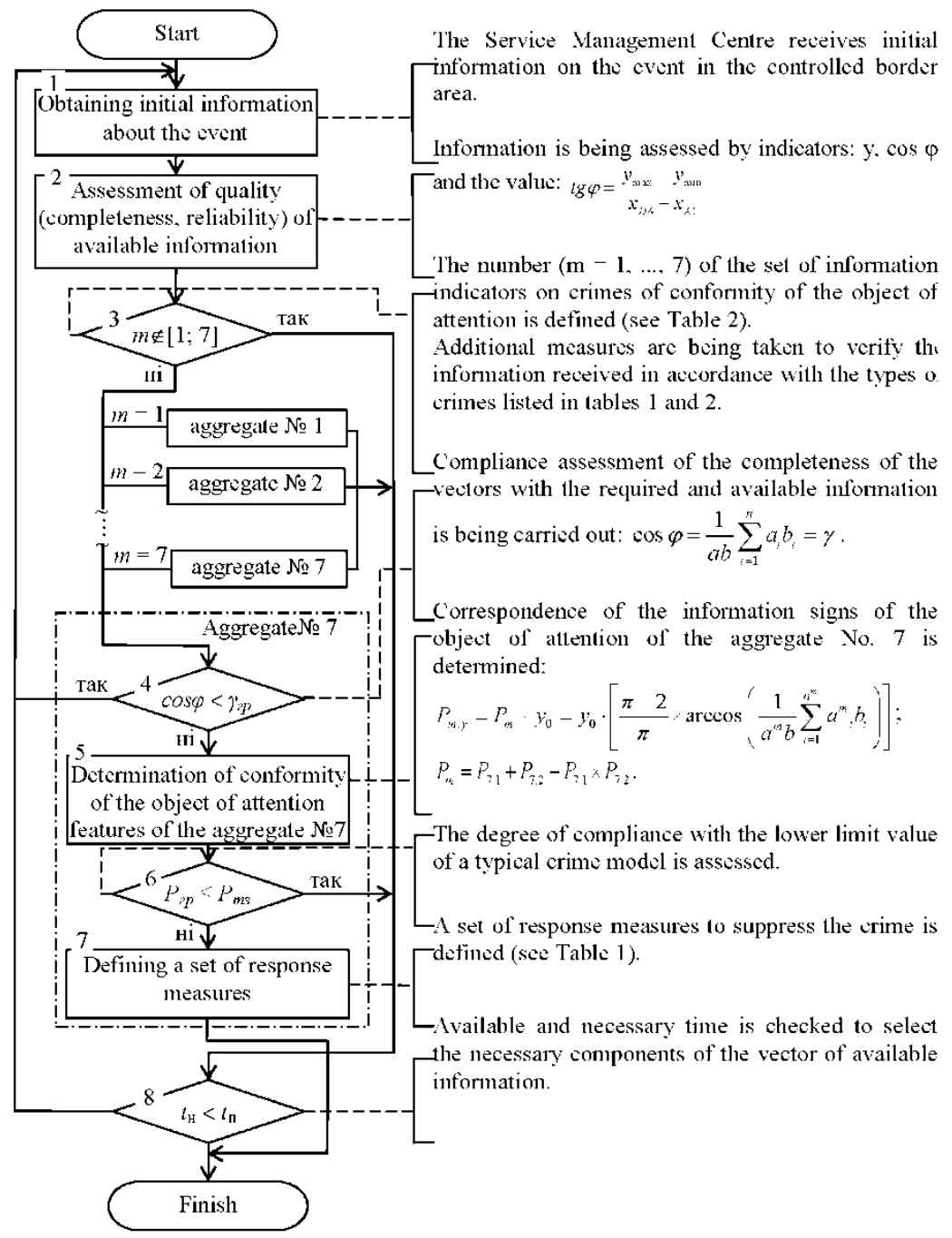

Fig. 1. Algorithm of identification of criminal activity on the State Border of Ukraine

\section{CONCLUSIONS}

A scientific approach to the formation of an adaptive model of identification of criminal activity on the state border of Ukraine is proposed. 
According to the legislation of Ukraine, a group of crimes has been selected to be countered by the forces and means of the State Border Guard Service of Ukraine.

Based on the available results of the operational and service activities of the bodies and units of the State Border Guard of the State Border Guard Service of Ukraine, a set of information indicators of crimes has been formed, for the commission of which liability is provided for in the Criminal Code of Ukraine.

Using the example, the procedure for comparing the obtained data on events at the state border in each of the aggregate of information signs of a particular type of crime and the relevant calculations is proposed.

\section{SUMMARY}

In the article the presented adaptive model and algorithm of identification of criminal activity on the state border of Ukraine provide an opportunity for the bodies and units of the State Border Protection of the SBGSU to determine the specific type of crime using the abovementioned values. As a result, this will allow for the timely adoption of measures for preventing and suppressing crimes.

This toolkit may also be used in other law enforcement agencies of Ukraine to identify criminal activity by its types.

Thus, the proposed adaptive model and algorithm of identification of criminal activity on the state border of Ukraine provide an opportunity for the bodies and units of the state border protection of the SBGSU to determine the specific type of crime using these expressions. As a result, it will allow taking timely measures to prevent and suppress crimes.

An adaptive model of the criminal activity identification according to a specific type of crime, which is being prepared or can be committed on the state border of Ukraine, is proposed. Using the presented algorithm, the Border Police and Border Protection Authorities and Departments are enabled to identify the type of crime at once and to take appropriate response measures.

This toolkit can also be used for other law enforcement agencies of Ukraine.

\section{REFERENCES}

1. Pro nacionaljnu bezpeku Ukrajiny : Zakon Ukrajiny : vid 21.06.2018 № 2469-VIII. URL : http:// www.rada.gov.ua. (in Ukrainian)

2. Ghorodnov V.P., Binjkovsjkyj O. A., Karatajev R. Gh., Kyrylenko V. A. (2009) Metodyka vyznachennja pokaznyka stupenja zaghostrennja obstanovky $\mathrm{v}$ prykordonnij sferi pry ocinci dynamiky formuvannja zaghrozy terytorialjnoji cilisnosti derzhavy [The method of 
determining the indicator of the degree of exacerbation of the situation in the border area in assessing the dynamics of the formation of threat to the territorial integrity of the state]. Zbirnyk naukovykh pracj, no. 46. pp. 24-31. (in Ukrainian)

3. Kyrylenko V. A, Gorodnov V. P, Karatayev R. G, Tsibrovskyi M. Yu. (2008) Model of determining the degree of correspondence of an object of attention to the data about a potential illegal migrant at border crossing points [Model for determining whether the object of attention is subject to data on a potential illegal migrant at border crossings]. Zbirnyk naukovykh pracj, no. 46. pp. 29-34. (in Ukrainian)

4. Androshhuk O. S., Mykhajlenko O. V. (2014) Modelj vyjavlennja porushnykiv zakonodavstva na derzhavnomu kordoni iz zastosuvannjam ijerarkhichnogho nechitkogho loghichnogho vyvodu [A model for determining the degree of compliance of an object of attention with data on a potential illegal migrant at border crossings]. Modern information technologies in the field of security and defense. no. 1(19). pp. 5-10. (in Ukrainian)

5. Cyghykal P. O, Farion O. B. (2017) Modelj rozpiznannja zlochyniv operatyvno-rozshukovym viddilom Derzhavnoji prykordonnoji sluzhby Ukrajiny [Model of crime recognition by the Operational Investigation Division of the State Border Guard Service of Ukraine]. Zbirnyk naukovykh pracj, no. 1(71). pp. 238-255. (in Ukrainian)

6. Onyshhuk S. V. (2014) Proghnozuvannja protypravnoji dijaljnosti na derzhavnomu kordoni poza punktamy propusku na osnovi nechitkoji loghiky [Predicting unlawful activities at the state border beyond the border crossing points based on fuzzy logic]. Zbirnyk naukovykh pracj, no. 3(40). pp. 198-202. (in Ukrainian)

7. Pro zatverdzhennja Polozhennja pro orghan okhorony derzhavnogho kordonu Derzhavnoji prykordonnoji sluzhby Ukrajiny: nakaz MVS vid 30.11.2018. \# 971. Kyjiv. URL: http://search.ligazakon.ua/ 1_doc2.nsf/link1/RE32920.html. (in Ukrainian)

8. Kryminaljnyj kodeks Ukrajiny : Zakon Ukrajiny \# 2341 III vid 05.04.2001 rok URL: http://zakon3.rada.gov.ua/laws/show/234114/para273. (in Ukrainian)

9. Pro zatverdzhennja Polozhennja pro informacijno-telekomunikacijnu systemu prykordonnogho kontrolju "Ghart-1" Derzhavnoji prykordonnoji sluzhby Ukrajiny : nakaz DPSU vid 30.09.2008. № 810. URL : https://zakon.rada.gov.ua/ laws/show/z1086-08. (in Ukrainian)

10. Streljbicjkyj M. A. (2018) Tekhnologhija zabezpechennja funkcionaljnoji bezpeky integhrovanoji informacijnoji systemy Derzhprykordonsluzhby na stadiji modernizaciji [Technology of providing 
functional security of the State Border Service's integrated information system at the stage of modernization], Kiev, 348 p. (in Ukrainian)

11. Shynkaruk O. M., Fedorchenko A. V. (2015) Analiz dosvidu stvorennja ta vykorystannja integhrovanykh telekomunikacijnykh system «Ghart» v Derzhavnij prykordonnij sluzhbi Ukrajiny [Analysis of the experience of creation and use of integrated telecommunication systems «Hart» in the State Border Service of Ukraine]. Zbirnyk naukovykh pracj, no. 2 (64), pp. 221-233. (in Ukrainian)

12. Pro zatverdzhennja Instrukciji pro porjadok ocinky informaciji za metodom 4kh4 : nakaz Administraciji Derzhavnoji prykordonnoji sluzhby Ukrajiny vid 19.01.08 \# 44. Kyjiv: ADPSU, 2008. 28 s. (in Ukrainian)

13. Ghorodnov V. P. Karatajev R. Gh., Kyrylenko V. A. (2009) Modelj vyznachennja stupenja vidpovidnosti ob'jekta uvaghy danym pro potencijnogho porushnyka $\mathrm{v}$ punktakh propusku cherez derzhavnyj kordon [Model for determining the degree of compliance of the object of attention to the information about the potential offender at the border crossing points]. Zbirnyk naukovykh pracj, no. 46. pp. 18-23. (in Ukrainian)

14. Medvedjev M. Gh., Pashhenko I. O. (2008) Teorija jmovirnostej ta matematychna statystyka [Probability theory and mathematical statistics]. Kiev : «Lira-K», 536 p. (in Ukrainian)

\section{Information about the author: Oleh Shynkaruk,}

Doctor of Technical Sciences, professor, rector, Bohdan Khmelnytskyi National Academy of the State Border Guard Service of Ukraine 46 Shevchenka str., Khmelnitskyi, 29007, Ukraine

ORCID ID: orcid.org/0000-0003-4499-8282 